\title{
Methodology for substantiation of technical and economic indicators of PSPP in energy water management systems of Uzbekistan
}

\author{
Muradilla Mukhammadiev ${ }^{*}$, Kurbon Dzhuraev, Sanjar Juraev, Abdurauf Abduaziz Uulu \\ and $A$ Makhmudov
}

Tashkent state technical university, Tashkent, Uzbekistan

\begin{abstract}
In our country, a lot of attention is paid to the development of the energy sector. A lot of work is underway to modernize existing capacities and commission new capacities. At the same time, the unit capacities of units and power plants also increase, which ensures faster commissioning of capacities in the power system and an increase in the efficiency of power plants. Attention is also paid to the development of power plants based on renewable energy sources (hydraulic, solar, wind, etc.). One of the most important tasks in the power industry is to cover peak minimum and maximum loads, which is becoming increasingly important in connection with the growth of the power system's capacity. As is known, according to world indicators, the maneuverable capacities should be about $25 \%$ of the total power of the EPS. The most promising maneuverable capacities are hydroelectric power plants. However, in our country, hydroelectric power plants account for about $14.3 \%$. This task will become more complicated with the introduction of capacities based on solar and wind energy and the commissioning of new hydroelectric and thermal power plants in the Republic. This is because RES capacities have a significant discontinuity even during the day, and the water resources in the Republic are primarily for irrigation and drainage purposes and are significantly variable during the season. One way to solve these problems in the world is the creation and use of pumped storage power plants (PSPP). The peculiarities of the creation and use of pumped storage power plants in our region are that the available hydro resources of our region are mainly of water management importance, while the task is also to increase the energy efficiency of existing reservoirs. Based on the foregoing, we can say that the development of methods for determining the economic efficiency of pumped storage power plants, taking into account direct and indirect effects, taking into account the peculiarities of their use in energy and water management systems of Uzbekistan is the main task for the present time. To solve the set tasks, a new methodology and program for substantiating the technical and economic indicators of pumped storage power plants in Uzbekistan's energy and water management systems have been developed. The schemes of using pumped storage power plants at four energy and water management facilities, that is, the Tuyamuyun hydro
\end{abstract}

\footnotetext{
* Corresponding author: muhammadiev_m@rambler.ru
} 
subunit, Arnasai, Talimarjan, and Khodjikent reservoirs, were considered, and for these facilities, based on the developed methodology and program, their technical and economic parameters of the pumped storage power plant were determined. Based on the results obtained, it can be said that using the PSPP in four facilities, it is possible to generate a total of about 418 MW of capacity and more than 930.0 million kWh of electricity, as well as to save 139 thousand tons of fuel equivalent per year, with this, the annual economic efficiency will be about 700.0 billion sums.

\section{Introduction}

At present, the available generating capacity of the electric power system (EPS) of Uzbekistan is $12.9 \mathrm{GW}$, of which in TPPs - $11 \mathrm{GW}$ or 84.7 percent, in HPPs - $1.85 \mathrm{GW}$ or 14.3 percent, in block stations and isolated stations - more than $0.133 \mathrm{GW}$ or 1 percent.

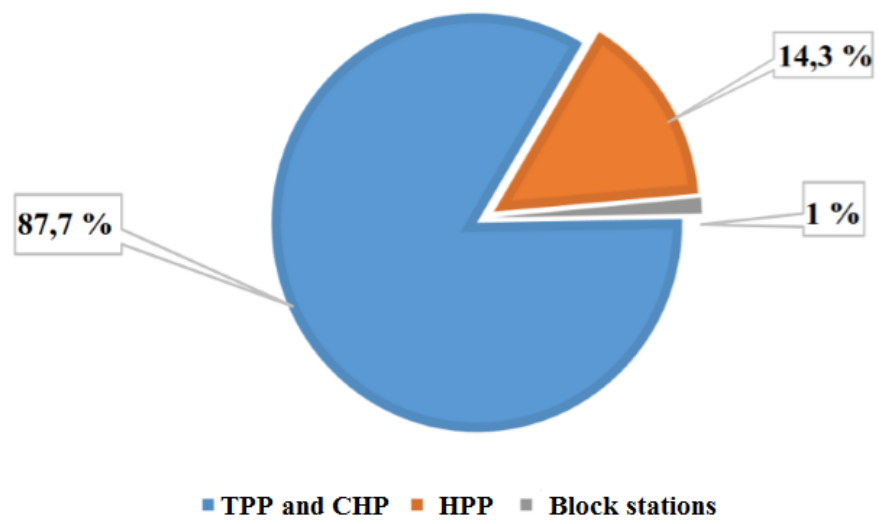

Fig. 1. The structure of electricity generation in the EPS of Uzbekistan

As seen from fig.1, the main source of generation is $11 \mathrm{TPPs}$, including 3 combined heat and power plants. In 2019, TPPs generated 89.6 percent of the total electricity generated within the Republic. At the same time, the total capacity of power units operating during the hours of maximum loads of the unified EPS was 8.6 GW.

Hydropower includes 42 HPPs, including 12 large ones with a total capacity of $1.68 \mathrm{GW}$ (90.8 percent of the total HPP capacity), 28 SHPPs with a total capacity of $0.25 \mathrm{GW}$ (13.5 percent), and 2 micro HPPs with a total capacity of $0.5 \mathrm{MW}$. The utilization rate of the Republic's hydro potential is 27 percent.

In Uzbekistan, to achieve the indicators of the development of renewable energy, the target parameters of the annually commissioned capacities of renewable energy sources (RES) in 2020-2030 have been determined, providing for the construction of $3 \mathrm{GW}$ wind and $5 \mathrm{GW}$ solar power plants.

However, along with the positive aspects of the development and saturation of the energy system of Uzbekistan with large power plants of enormous capacity, it aggravates the difficulties in covering the minimum and maximum daily loads of EPS (fig. 2). 


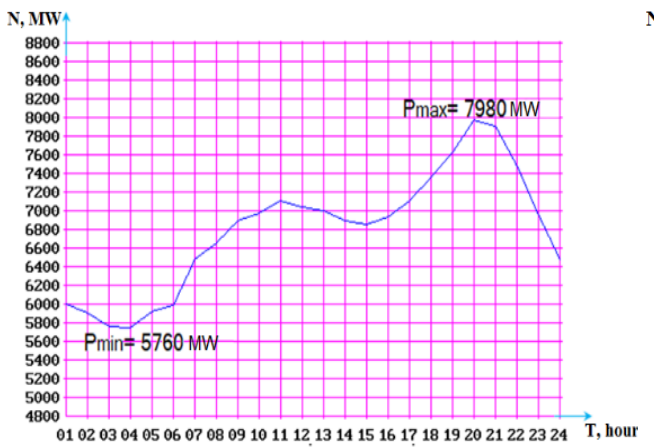

a)

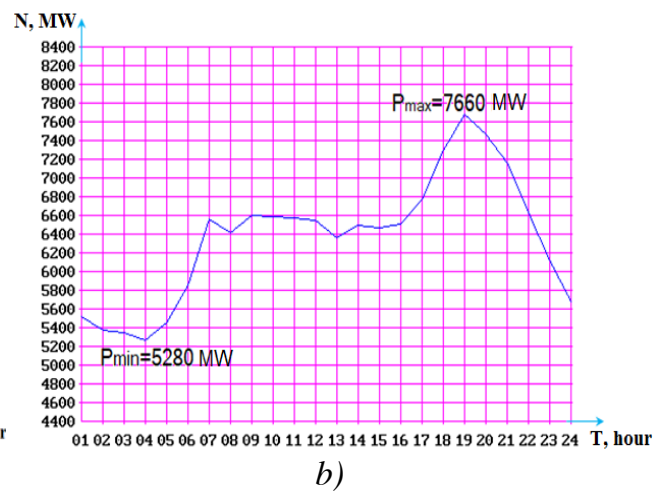

b)

Fig. 2. Diagrams of daily loads of EPS of the Republic of Uzbekistan a) 09.10.2019; b) 15.04.2020.

The limited range of power regulation of large-block units and the impossibility of frequent starts and stops without a sharp decrease in the reliability and efficiency of the operation of the power equipment of thermal power plants, as well as power plants based on renewable energy sources (solar, wind, etc.), which have significant discontinuity even during the day, leads to difficulty covering the uneven part of the electrical load curves and lead to the need to increase maneuverable capacities.

From 2012 to 2019, there was an increase in electricity production at an average of 2.6 percent per year. However, the demand for electric energy was not fully satisfied. The deficit was about 9.4 percent of the demand (figure 3).

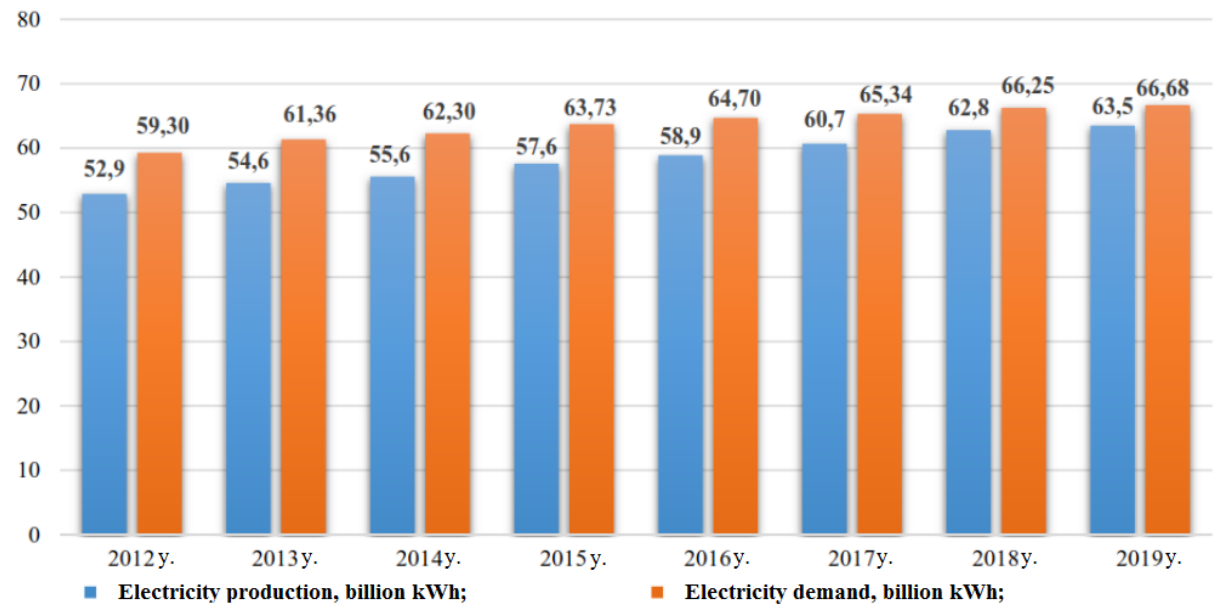

Fig. 3. Factual dynamics of production and demand for electric energy in the period 2012-2019

The maximum load during the peak hours of electricity consumption in winter 2019 was $10.4 \mathrm{GW}$. The difference between the minimum and maximum load was $2.3 \mathrm{GW}$. At the same time, in the summer of 2019, the peak indicator reached $9.4 \mathrm{GW}$ with a difference between the minimum load of $2.6 \mathrm{GW}$ (figure 4). 


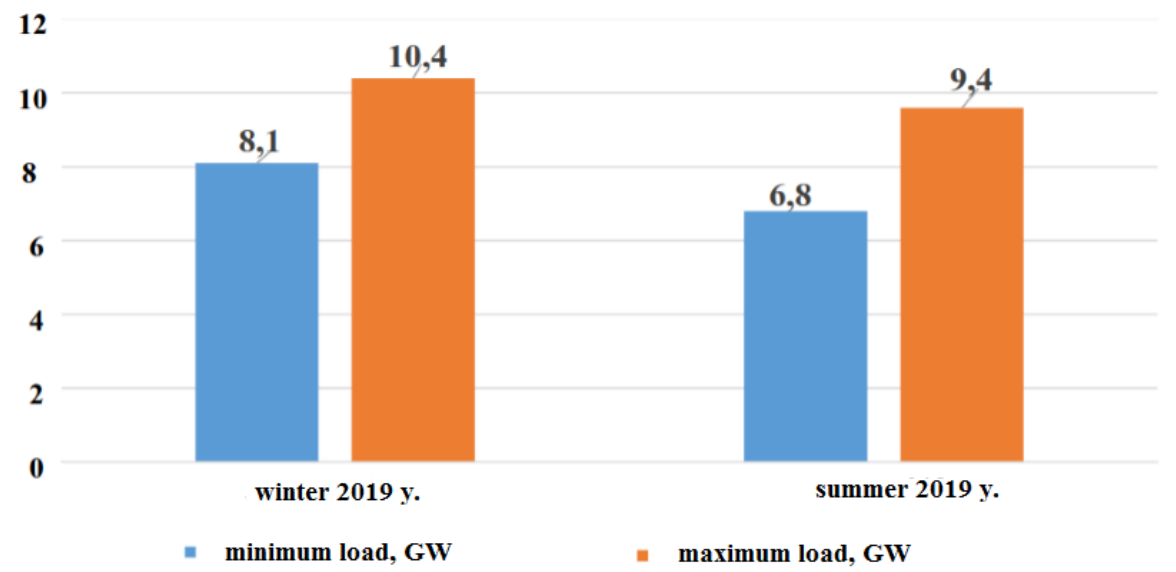

Fig. 4. Minimum and maximum loads for the winter and summer period 2019.

In this direction, special attention in the world is paid to developing new methods for the design, construction, and use of pumped storage power plants (PSPP) and installations that have the best maneuverability compared to other types of maneuverable power plants (HPP, GTU).

For Uzbekistan, it is of particular importance to carrying out research work to improve the maneuverability, reliability, and stability of the EPS with the help of PSPPs, in particular aimed at solving problems, determining the optimal energy-hydraulic and operating parameters, and technical and economic indicators of PSPPs based on increasing their energy, economic and environmental efficiency and taking into account the peculiarities of their use in the energy and water management system (EWMS) of Uzbekistan.

In the economy, methods have now been developed for assessing the economic efficiency of various energy facilities. However, in connection with the increasing urgency of environmental problems, there is a further development of methods for determining power plants' economic efficiency, which allows taking into account environmental issues. In particular, in $[15,21]$, it was shown that in assessing the efficiency of a PSPP, in addition to its main task - maneuverable capacity, it is also necessary to take into account the possibilities of increasing the reliability and efficiency of existing energy facilities and water management systems, fuel savings, which also contribute to a decrease in greenhouse gas emissions, and improvement in the ecological state of water - an increase in oxygen saturation.

The development of a methodology for determining the economic efficiency of a PSPP, taking into account direct and indirect effects, is the main task in the design of PSPPs for the conditions of Uzbekistan.

\section{Methods}

For this purpose, a methodology has been developed for determining the economic indicators of a PSPP, which allows solving the higher specified problem and makes it possible to determine - capital investments in PSPP $\left(K_{P S P P}\right)$, electricity generation in turbine mode $(\mathrm{TM})\left(E_{T M}\right)$, electricity consumption in pumping mode $(\mathrm{PM})\left(E_{P M}\right)$, annual savings in fuel resources $\left(D_{\text {fuel }}\right)$, fuel economy $\left(E_{f u e l}\right)$, the annual cost of PSPP $\left(I_{P S P P}\right)$, economic 
efficiency per year $\left(E_{P S P P}\right)$, payback period $\left(\mathrm{T}_{\text {payback }}\right)$ and profitability of capital investments $\mathrm{R}$.

As you know, economic efficiency in the general case is the difference between income and costs. Consider the economic characteristics of the PSPP, taking into account the features mentioned above of its application capital investments in PSPP $K_{P S P P}$ are generally equal:

$$
K_{P S P P}=N_{T M} \cdot \alpha_{P S P P},[\mathrm{sum}]
$$

where, $\alpha_{P S P P}$ is specific capital investment, sum $/ \mathrm{kW}$;

Annual electricity generation in $\mathrm{TM} E_{T M}$ :

$$
E_{T M}=365 \cdot t_{T M} \cdot N_{T M},[\mathrm{kWh}]
$$

where, 365 is days of the year; $t_{T M}$ is operating time of the PSPP in TM during the day. Electricity consumption in PM $\mathrm{E}_{\mathrm{PM}}$ :

$$
E_{P M}=365 \cdot t_{P M} \cdot N_{P M},[\mathrm{kWh}]
$$

$t_{P M}$ is operating time of the PSPP in PM during the day.

Savings in foreign currency while reducing the purchase of peak electricity from neighboring power systems $S_{\$}[14]$ :

$$
S_{\$}=E_{T M} \cdot \beta_{P M},[\mathrm{USD}]
$$

$\beta_{\$}$ is cost of $1 \mathrm{kWh}$ of peak electricity in neighboring power systems, USD/kWh. Cost of $1 \mathrm{kWh}$ of peak electricity in the EPS of Uzbekistan $\beta_{T M}[19,23]$ :

$$
\beta_{T M}=1,4 \cdot \beta_{E},[\mathrm{sum} / \mathrm{kWh}]
$$

$\beta_{E}$ is electricity tariff in the normal period of the EPS load schedule, sum $/ \mathrm{kWh}$; The cost of $1 \mathrm{kWh}$ of electricity during the load failure period in the EPS $\beta_{P M}[17,22]$ :

$$
\beta_{P M}=0,7 \cdot \beta_{E},[\mathrm{sum} / \mathrm{kWh}]
$$

The cost of electricity generated by the PSPP during the peak $S_{T M}$ period:

$$
S_{P M}=E_{T M} \cdot \beta_{T M},[\text { sum }]
$$

The cost of electricity consumed by PSPP in PM $S_{P M}$ occurs during periods of load failure, or:

$$
S_{P M}=E_{P M} \cdot \beta_{P M},[\text { sum }] .
$$

Annual savings in fuel resources $D_{\text {fuel }}$ : 


$$
D_{\text {fuel }}=\gamma \cdot E_{P M},[\mathrm{~kg} . \mathrm{c} . \mathrm{f}]
$$

$\gamma$ is specific fuel economy per $1 \mathrm{kWh}$ of electricity in the PSPP, kg.c.f./kWh. Fuel economy $E_{f u e l}$ :

$$
E_{\text {fuel }}=D_{\text {fuel }} \cdot \beta_{\text {fuel }},[\text { sum }]
$$

$\beta_{\text {fuel }}$ is cost of $1 \mathrm{~kg} . c . f$, sum $/ \mathrm{kg} . \mathrm{c} . \mathrm{f}$.

Annual costs of PSPP $I_{P S P P}[15]$ :

$$
I_{P S P P}=I_{d e p}+I_{s e r}+I_{w a g e}+I_{o e},[\mathrm{sum}]
$$

where $I_{d e p}$ is depreciation deductions for PSPP are taken the same as for HPP, or $5 \%$ of capital investments for the creation of PSPP $K_{P S P P}$ :

$$
I_{d e p}=0,05 \cdot K_{P S P P},[\mathrm{sum}]
$$

$I_{\text {ser }}$ are repair costs, $18 \%$ of $I_{\text {dep }}$

$$
I_{\text {ser }}=0,18 \cdot I_{d e p}=0,05 \cdot 0,18 \cdot K_{P S P P}=0,009 \cdot K_{P S P P},[\mathrm{sum}] .
$$

$\mathrm{I}_{\text {wage }}$ is salary of service personnel:

$$
I_{\text {wage }}=\Delta I_{\text {wage }} \cdot n_{\text {per }},[\text { sum }]
$$

where $n_{p e r}$ is number of personnel; $\Delta I_{\text {wage }}$ is staff salary; $I_{o e}$ are other expenses (overheads):

$$
I_{o e}=0,15 \cdot\left(I_{\text {dep }}+I_{\text {ser }}+I_{\text {wage }}\right)=0,15 \cdot\left(0,059 \cdot K_{P S P P}+n_{\text {per }} \cdot \Delta I_{\text {wage }}\right),[\mathrm{sum}] .
$$

As a result, for a PSPP with a capacity of more than $100 \mathrm{~kW}$ :

$$
I_{P S P P}=0,06785 \cdot K_{P S P P}+1,15 \cdot \Delta I_{\text {wage }} \cdot n_{p e r},[\mathrm{sum}]
$$

For pumped storage power plants with a capacity of less than $100 \mathrm{~kW}\left(I_{o e}=0\right.$ and $\left.I_{\text {wage }}=0\right)$

$$
I_{P S P P}=0,05 \cdot K_{P S P P}+0,009 \cdot K_{P S P P}=0,059 \cdot K_{P S P P} .
$$

And the annual economic efficiency of the PSPP $E_{P S P P}$ will be equal to

$$
E_{P S P P}=S_{T M}+E_{f u e l}+E i-I_{P S P P}-S_{P M}-0,15 \cdot K_{P S P P},[\mathrm{sum}] .
$$

where $E i$ is indirect economic effects, including the effects of reducing greenhouse gas emissions from $E_{G G}$, improving the operating modes of existing energy facilities (increasing the reliability and efficiency) of the $E_{E O}$ and increasing the reliability of the EPS $E_{P S}$, or 


$$
E i=E_{G G}+E_{E O}+E_{E S},[\mathrm{sum}]
$$

The effect of reducing greenhouse gas emissions due to PSPP is determined through the expression

$$
E_{G G}=E \cdot \beta_{C O 2},[\mathrm{sum}]
$$

where $\beta_{\mathrm{CO} 2}$ are annual costs of environmental measures to remove $\mathrm{CO}_{2}$ are taken $15 \ldots$ $20 \$ /$ ton $[4,6,20]$; $\mathrm{E}$ is annual $\mathrm{CO}_{2}$ emission, for each type of fuel (combustion plants) is produced according to the formula:

$$
E=M \cdot K_{1} \cdot N C V \cdot K_{2} \cdot 44 / 12,[\text { tons/year] }
$$

where $\mathrm{M}$ is actual fuel consumption for the year:

$$
M=\gamma \cdot E_{P M},[\text { tons } / \text { year }]
$$

where $K_{l}$ is oxidation factor of carbon in the fuel (shows the fraction of burned carbon), $K_{l}=0.98-0.995 ; N C V$ is net calorific value, $\mathrm{J} /$ ton; $K_{2}$ is carbon emission factor, ton $/ \mathrm{J} ; 44 / 12$ is coefficient of conversion of carbon into carbon dioxide (molecular weights, respectively: carbon is $12 \mathrm{~g} / \mathrm{mol}, \mathrm{O}_{2}=2 \cdot 16=32 \mathrm{~g} / \mathrm{mol}, \mathrm{CO}_{2}=44 \mathrm{~g} / \mathrm{mol}$ ).

Determination of the actual fuel consumption is based on the accounting data of the enterprise on the consumption of various types of fuel.

Indirect components of the economic effect of $E_{E O}$ and $E_{E S}$ can be calculated based on data on the characteristics of the operation of existing energy facilities and power systems efficiency, reliability, stability.

The formulas obtained are general. However, there are some peculiarities when assessing the economic effects for PSPP with less than $100 \mathrm{~kW}$ capacity. So, for example, the component of $0.15 \cdot K_{P S P P}$ (other expenses - costs for infrastructure, ecology, etc.) and the indirect effects of $E_{E O}$ and $\mathrm{E}_{\mathrm{ES}}$ are not taken into account.

Payback period of capital investments $\mathrm{T}_{\text {payback }}$ at the PSPP will be equal to $[16,19]$ :

$$
T_{\text {payback }}=\frac{K_{P S P P}}{E_{P S P P}}, \text { [year] }
$$

or the return on investment $\mathrm{R}$ in the PSPP is [12]:

$$
R=\frac{E_{P S P P}}{K_{P S P P}}
$$

Based on this methodology, which also takes into account indirect effects, a program was developed [22], which provides determination of the PSPP capacity in TM and PM, the required useful volume of water, the annual electricity generated in the TM, and the consumed electricity for water accumulation in the PM, the efficiency, capital investments for the creation of a PSPP, the cost of the annual generated and consumed electricity, the annual savings of fuel resources and its monetary value, the annual costs of PSPP, the 
annual economic efficiency from the creation of PSPP, taking into account indirect effects, the payback period of the investment and the profitability ratio.

\section{Results and Discussion}

Based on the developed methodology and program, the technical and economic indicators of pumped storage power plants were investigated when EWMS used them at the Tuyamuyun hydro subunit, Arnasai, Talimarjan, and Khodjikent reservoirs (Fig. 5), and the results are given in tables $1 \div 3$.

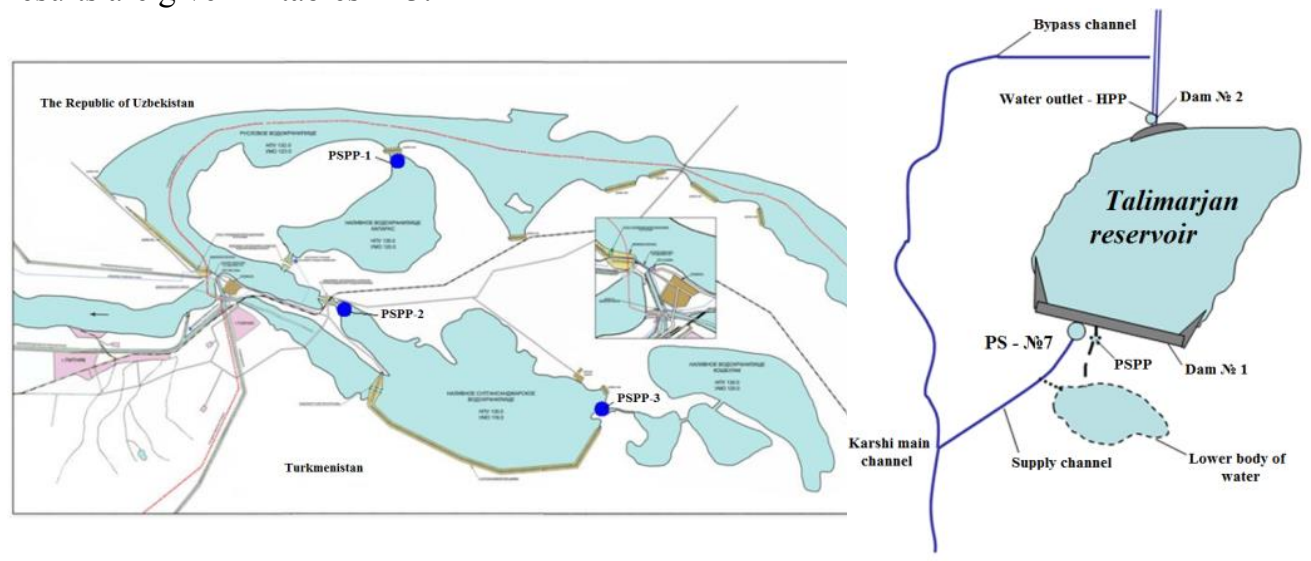

a)

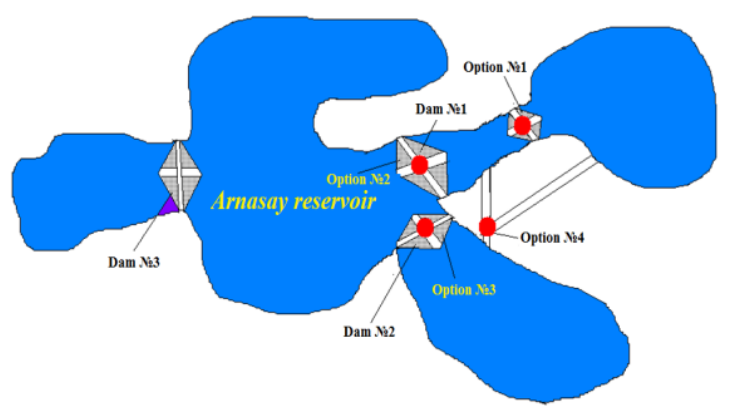

v) b)

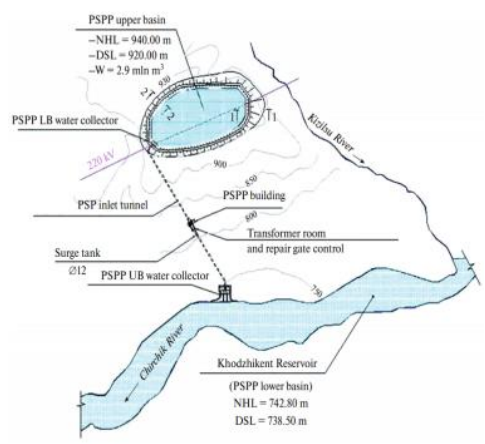

d)

Fig. 5. Schemes of the proposed EWMS using PSPP:

a) scheme of the Tuyamuyun hydro subunit; $b$ ) scheme of the Talimarjan reservoir;

v) scheme of the Arnasai reservoir; $d$ ) scheme of the Khodjikent reservoir. 
Table 1. Main technical and economic indicators of pumped storage power plants when using them at Tuyamuyun hydro subunit

\begin{tabular}{|c|c|c|c|c|c|}
\hline \multirow[t]{2}{*}{ № } & \multirow[t]{2}{*}{ The name of indicators } & \multirow{2}{*}{$\begin{array}{l}\text { Unit of } \\
\text { measurement }\end{array}$} & \multicolumn{3}{|c|}{$\begin{array}{l}\text { The values of the PSPP at the } \\
\text { Tuyamuyun hydro subunit }\end{array}$} \\
\hline & & & PSPP 1 & PSPP 2 & PSPP 3 \\
\hline 1 & Pressure in TM & $m$ & 7.87 & 6.7 & 5.8 \\
\hline 2 & Pressure in PM & $m$ & 10.1 & 9.2 & 7.7 \\
\hline 3 & Consumption in TM & $\mathrm{m}^{3} / \mathrm{sec}$ & 214 & 234 & 246 \\
\hline 4 & Consumption in PM & $\mathrm{m}^{3} / \mathrm{sec}$ & 170 & 180 & 190 \\
\hline 5 & $\begin{array}{c}\text { The volume of water } \\
\text { used for accumulation } \\
\text { per day }\end{array}$ & $m \ln . m^{3}$ & 4.62 & 5.05 & 5.31 \\
\hline 6 & Power in TM & $k W$ & 14209 & 13273 & 11939 \\
\hline 7 & Power in PM & $k W$ & 19793 & 19180 & 17147 \\
\hline 8 & $\begin{array}{l}\text { The efficiency of the } \\
\text { PSPP }\end{array}$ & $\%$ & 73.19 & 73.10 & 73.40 \\
\hline 9 & Capital investment & billion. sum & 50.72 & 47.38 & 42.62 \\
\hline 10 & $\begin{array}{l}\text { Electricity generation } \\
\text { in TM per year }\end{array}$ & million. $k W h$ & 31.117 & 29.068 & 26.147 \\
\hline 11 & $\begin{array}{l}\text { Annual electricity } \\
\text { consumption in PM }\end{array}$ & million. $k W h$ & 54.566 & 54.605 & 48.620 \\
\hline 12 & $\begin{array}{l}\text { The cost of generated } \\
\text { electricity during the } \\
\text { peak period per year }\end{array}$ & million. sum & 9958.739 & 9302.910 & 8368.151 \\
\hline 13 & $\begin{array}{l}\text { The cost of consumed } \\
\text { electricity in PM per } \\
\text { year }\end{array}$ & million. sum & 8731.583 & 8737.912 & 7780.146 \\
\hline 14 & $\begin{array}{c}\text { Annual savings in fuel } \\
\text { resources }\end{array}$ & t.s.f. & 4667.575 & 4360.194 & 3922.081 \\
\hline 15 & Yearly cost & million. sum & 3453.208 & 3226.556 & 2903.506 \\
\hline 16 & $\begin{array}{l}\text { Economic efficiency } \\
\text { per year }\end{array}$ & million. sum & 9116.314 & 7933.105 & 7213.451 \\
\hline 17 & $\begin{array}{l}\text { Payback period of } \\
\text { capital investments }\end{array}$ & sut & 5.56 & 5.97 & 5.91 \\
\hline 18 & Return on investment & $\%$ & 0.177 & 0.165 & 0.167 \\
\hline
\end{tabular}


Table 2. The main technical and economic indicators of PSPP when using them in the Arnasai reservoir

\begin{tabular}{|c|c|c|c|c|c|c|}
\hline \multirow[b]{2}{*}{ № } & \multirow{2}{*}{$\begin{array}{l}\text { The name of } \\
\text { indicators }\end{array}$} & \multirow{2}{*}{$\begin{array}{c}\text { Unit of } \\
\text { measurement }\end{array}$} & \multicolumn{4}{|c|}{ The values of the PSPP at the Arnasai reservoir } \\
\hline & & & Option 1 & Option 2 & Option 3 & Option 4 \\
\hline 1 & Pressure in TM & $m$ & 12 & 9 & 6 & 15 \\
\hline 2 & Pressure in PM & $m$ & 14.4 & 10.8 & 7.2 & 18 \\
\hline 3 & $\begin{array}{l}\text { Consumption } \\
\text { in TM }\end{array}$ & $\mathrm{m}^{3} / \mathrm{sec}$ & 440 & 480 & 500 & 420 \\
\hline 4 & $\begin{array}{l}\text { Consumption } \\
\text { in PM }\end{array}$ & $\mathrm{m}^{3} / \mathrm{sec}$ & 360 & 390 & 400 & 340 \\
\hline 5 & $\begin{array}{l}\text { The volume of } \\
\text { water used for } \\
\text { accumulation } \\
\text { per day }\end{array}$ & million. $\mathrm{m}^{3}$ & 9.50 & 10.37 & 10.80 & 9.07 \\
\hline 6 & Power in TM & $k W$ & 44545 & 36573 & 25104 & 53620 \\
\hline 7 & Power in PM & $k W$ & 59480 & 48554 & 33755 & 69892 \\
\hline 8 & $\begin{array}{l}\text { The efficiency } \\
\text { of the PSPP }\end{array}$ & $\%$ & 73.53 & 73.44 & 71.40 & 74.53 \\
\hline 9 & $\begin{array}{c}\text { Capital } \\
\text { investment }\end{array}$ & billion. sum & 159.02 & 130.56 & 89.62 & 191.42 \\
\hline 10 & $\begin{array}{l}\text { Electricity } \\
\text { generation in } \\
\text { TM per year }\end{array}$ & million. $k W \cdot h$ & 97.554 & 80.095 & 54.977 & 117.428 \\
\hline 11 & $\begin{array}{c}\text { Annual } \\
\text { electricity } \\
\text { consumption in } \\
\text { PM } \\
\end{array}$ & million. $k W \cdot h$ & 159.207 & 130.873 & 92.404 & 189.078 \\
\hline 12 & $\begin{array}{l}\text { The cost of } \\
\text { generated } \\
\text { electricity } \\
\text { during the peak } \\
\text { period per year }\end{array}$ & billion. sum & 31.22 & 25.63 & 17.60 & 37.58 \\
\hline 13 & $\begin{array}{l}\text { The cost of } \\
\text { consumed } \\
\text { electricity in } \\
\text { PM per year }\end{array}$ & billion. sum & 25.47 & 20.94 & 14.78 & 30.25 \\
\hline 14 & $\begin{array}{l}\text { Annual savings } \\
\text { in fuel } \\
\text { resources }\end{array}$ & thousand.t.s.f. & 14.633 & 12.014 & 8.247 & 17.614 \\
\hline 15 & Yearly cost & billion. sum & 10.80 & 8.87 & 6.09 & 13.00 \\
\hline 16 & $\begin{array}{c}\text { Economic } \\
\text { efficiency per } \\
\text { year }\end{array}$ & billion. sum & 30.53 & 25.03 & 16.76 & 37.16 \\
\hline 17 & $\begin{array}{c}\text { Payback period } \\
\text { of capital } \\
\text { investments }\end{array}$ & summer & 5.21 & 5.22 & 5.35 & 5.15 \\
\hline 18 & $\begin{array}{l}\text { Return on } \\
\text { investment }\end{array}$ & $\%$ & 18.904 & 18.883 & 18.420 & 19.120 \\
\hline
\end{tabular}


Table 3. Main technical and economic indicators of PSPP when using them in Talimarjan and Khodjikent reservoirs

\begin{tabular}{|c|c|c|c|c|}
\hline № & The name of indicators & $\begin{array}{c}\text { Unit of } \\
\text { measurement }\end{array}$ & $\begin{array}{l}\text { The values } \\
\text { of the PSPP } \\
\text { at the } \\
\text { Talimarjan } \\
\text { reservoir }\end{array}$ & $\begin{array}{c}\text { The values of } \\
\text { the PSPP at } \\
\text { the } \\
\text { Khodjikent } \\
\text { reservoir }\end{array}$ \\
\hline 1 & Pressure in TM & $m$ & 24.2 & 180 \\
\hline 2 & Pressure in PM & $m$ & 25.8 & 194 \\
\hline 3 & Consumption in TM & $\mathrm{m}^{3} / \mathrm{sec}$ & 90 & 130 \\
\hline 4 & Consumption in PM & $\mathrm{m}^{3} / \mathrm{sec}$ & 72 & 104 \\
\hline 5 & $\begin{array}{l}\text { The volume of water used } \\
\text { for accumulation per day }\end{array}$ & million. $m^{3}$ & 1.94 & 2.90 \\
\hline 6 & Power in TM & $k W$ & 18473 & 199991 \\
\hline 7 & Power in PM & $k W$ & 21314 & 233129 \\
\hline 8 & The efficiency of the PSPP & $\%$ & 73.92 & 73.56 \\
\hline 9 & Capital investment & billion. sum & 31.0 & 2839.1 \\
\hline 10 & $\begin{array}{c}\text { Electricity generation in } \\
\text { TM per year }\end{array}$ & million. $k W h$ & 40.456 & 452.6 \\
\hline 11 & $\begin{array}{l}\text { Annual electricity } \\
\text { consumption in PM }\end{array}$ & million. $k W h$ & 58.346 & 659.5 \\
\hline 12 & $\begin{array}{l}\text { The cost of generated } \\
\text { electricity during the peak } \\
\text { period per year }\end{array}$ & billion. sum & 12.95 & 158.41 \\
\hline 13 & $\begin{array}{l}\text { The cost of consumed } \\
\text { electricity in PM per year }\end{array}$ & billion.sum & 9.33 & 115.41 \\
\hline 14 & $\begin{array}{l}\text { Annual savings in fuel } \\
\text { resources }\end{array}$ & $\begin{array}{l}\text { thousand. } \\
\text { t.s.f. }\end{array}$ & 6.07 & 67.90 \\
\hline 15 & Yearly cost & billion. sum & 2.12 & 192.65 \\
\hline 16 & $\begin{array}{l}\text { Economic efficiency per } \\
\text { year }\end{array}$ & billion. sum & 5.44 & 564.55 \\
\hline 17 & $\begin{array}{c}\text { Payback period of capital } \\
\text { investments }\end{array}$ & summer & 5.7 & 5.029 \\
\hline 18 & Return on investment & $\%$ & 0.175 & 0.199 \\
\hline
\end{tabular}

Based on the results given in tables $1 \div 3$, we can say that:

- the considered PSPP options, differing in the location of PSPP in the Tuyamuyun hydroelectric power station, are almost the same from an economic point of view, which shows the possibility of creating at this hydroelectric facility the interstate use of the hydropotentials of its reservoirs when using PSPP. This will increase the stabilization of the operation modes of the EPS of Turkmenistan and Uzbekistan and receive an additional 86.5 million $\mathrm{kWh}$ of environmentally friendly electricity and, accordingly, peak capacities up to 39.4 MW using PSPP with an annual economic efficiency of 24.3 billion soums and fuel economy 12.95 thousand tons of fuel equivalent;

- all options for constructing a pumped storage power plant on the Arnasay reservoir are almost the same from an economic point of view; this also makes it possible to use the hydro potential of the Chardara and Arnasay reservoirs and improve the operating modes of the EPS in Kazakhstan and Uzbekistan. In general, this will make it possible to obtain at least 350.0 million $\mathrm{kWh}$ of electricity per year, to create a pumped storage power plant with a total capacity of $159.8 \mathrm{MW}$ with an annual economic efficiency of 
109.5 billion sums, including a fuel economy of 52.5 thousand tons of fuel equivalent. t.;

- the capacity of the PSPP at the Talimarjan reservoir can reach $18.473 \mathrm{MW}$, the annual economic efficiency can be 5.44 billion sums, and the peak electricity generation will be 40.456 million $\mathrm{kWh}$, and the fuel economy will be 6.07 thousand tons of fuel equivalent;

- the capacity of the Khojikent PSPP can be 200 MW with an annual output of 452.600 million kWh of electricity with an annual economic efficiency of 564.55 billion sum, including an annual fuel saving of 67.90 thousand tons of fuel equivalent.

\section{Conclusions}

1. The state and modes of operation of the EPS of the Republic of Uzbekistan show that to improve the functioning of the EPS, maneuverable capacities are needed, in particular, it indicates that this requires the creation of pumped storage power plants operating in the daily, weekly and seasonal mode of energy storage.

2. At present, the existing reservoirs of the Republic are mainly used for irrigation purposes, partly for drinking water supply. For complete use of the potential of water resources in the operated reservoirs, it is necessary to create hydropower complexes that, in their essence, are capable of solving the issues of electricity production during the depletion of reservoirs.

3. Terrain relief is of great importance in designing a PSPP - desirable to use local reservoirs and elevation differences to increase the pressure and thus improve its economic performance. In our region, it is necessary to take into account the new conditions for the creation of pumped storage power plants - low-pressure, at the same time high capacities, as well as the maximum use of existing reservoirs and watercourses, which are mainly of water economic importance.

4. The developed methodology for substantiating the technical and economic indicators of PSPP in Uzbekistan's energy and water systems and its software implementation can be used in the design and development of a feasibility study at PSPP and determining its optimal options.

5. The technical and economic indicators of the PSPP according to the developed methodology are preliminary; that is, the capacity of the projected PSPP will depend on the possibility of creating sufficient capacities of the upper and lower basins, and the injection and operation modes will be determined by the results of optimization technical and economic calculations for the requirements of the power system, taking into account the long-term strategy its development.

\section{References}

1. The concept of providing the Republic of Uzbekistan with electric energy for (20202030).

2. Mukhammadiev M.M., Dzhuraev K.S Justification of the energy and economic parameters of pumped storage power plants in Uzbekistan. International journal "Applied Solar Energy", Vol. 56, №3, pp.227-232. (2020).

3. Mukhammadiev M and Klichev Sh Use of Pumped Storage Hydroelectric Power Plants in Uzbekistan. International journal "Applied Solar Energy", Vol. 54, №6, pp.468-471. (2018). 
4. Mukhammadiev M, Urishev B Use and accumulation of renewable energy in the energy system of the Republic of Uzbekistan. Monograph, Tashkent, NURFAYZ, p. 252. (2020).

5. Mukhammadiev M, Urishev B, Mamadiyorov E and Dzuraev K Low-power power plants based on renewable energy sources. Monograph, Tashkent TDTU, p. 162. (2015).

6. Muhammadiev $\mathrm{M}$ and Urishev B. Hydroaccumulative power plants. Monograph. Publishing house "Fan va texnologiya", Tashkent, p. 212. (2018)

7. Mukhammadiev M, Dzhuraev K and Klychev Sh Capabilities of Hydroelectric PumpedStorage Stand-Alone Power Plants. International journal "Applied Solar Energy", Vol. 49, №4, pp. 267-271. (2013).

8. Klychev I. Sh., Mukhammadiev M. M., Nizamov O.Kh., Mamadierov E.K., Dzhuraev K.S., Saifiev A.U Method for calculating the power of combined autonomous electric power plants. International journal "Applied Solar Energy", Vol. 50, №3, pp.196-201. (2014).

9. Dzhuraev K., Nasrulin A., Shadibekova F., Kurbonov Sh Geoinformation systems at the selection of engineering infrastructure of pumped storage hydropower for the Tuyamuyun complex. IOP Conference Series: Materials Science and Engineering, Volume 869, Number 4, Engineering Infrastructure, IOP Publishing, pp.1-10

10. Muhammadiev M., Urishev B., Juraev S. and Boliev A 2020 Detritus removal from a pumping-plant intake chamber with hydrajet pumps. IOP Conference Series: Materials Science and Engineering, Volume 883, IOP Publishing, pp.1-8. (2020)

11. Mukhammadiev M, Nasrulin, A Mukolyants A and Ergasheva D A complexly method of GIS technologies and optimization models used in the development of environmentally acceptable modes of operation of hydraulic and hydropower facilities in Uzbekistan. Journal of Physics: Conference Series, Vol.1425. (2020).

12. Barbour E, Wilson I A G, Radcliffe J, Ding Y L and Li Y L A review of pumped hydroenergy storage development in significant international electricity markets Renew Sust Energ Rev, 61, pp. 421-432. (2016).

13. Guittet M, Capezzali M, Gaudard L, Romerio F and Vuille F F Study of the drivers and asset management of pumped-storage power plants historical and geographical perspective Energy 111, pp. 560-579. (2016).

14. Connolly D, Lund H and Mathiesen BV Smart Energy Europe: the technical and economic impact of one potential 100\% renewable energy scenario for the European Union Renew Sust Energ Rev, № 60 pp.1634-1653

15. Steffen B Prospects for pumped-hydro storage in Germany 2012 Energ Policy, 45 pp. 420-429. (2016).

16. Zhang S, Andrews-Speed $\mathrm{P}$ and Perera $\mathrm{P}$ The evolving policy regime for pumped storage hydroelectricity in China: a key support for low-carbon energy Appl Energy, 150 pp. 15-24. (2015).

17. Brandi A A 2014 Pumped storage hydropower: A Technical Review. B.S., University of Colorado, p. 84.

18. Utamuradova Sh.B., Daliev Kh.S., Daliev Sh.K, Fayzullaev K.M. The influence of chromium and iron atoms on the processes of defect formation in silicon. Applied Physics, (6), pp.90-95. (2019).

19. Yang C J (2010). Pumped Hydroelectric Storage: Technical report http://people.duke.edu/-cy42/

20. Denholm P, Ela E Kirby B and Milligan M (2010) The role of energy storage with renewable electricity generation Technical report NREL/TP-6A2-47187 
21. Urishev B.U. Increasing the efficiency of use and accumulation of hydraulic energy of renewable sources: abstract of thesis. Doctors of technical sciences: 05.05.06 - p. 73. Tashkent, (2018).

22. Nazari $M$, Ardehali $M$ and Jafari $S$ Pumped storage unit commitment with considerations for energy demand, economics, and environmental constraints. Energy; 35 (10), pp 4092-101. (2010).

23. Mukhammadiev M M, Dzuraev K S, Zhuraev S R, Kulanov Zh B and Mamatkulov D A The program for determining the energy - economic parameters of pumped storage power plants. Application for certificate of official registration of a computer program №. DGU07363 (2019).

24. M Mukhammadiev, O Glovatskiy, N Nasyrova, N Karimova, A Abduaziz uulu and A Boliev. Assessment of investment technologies for use of hydro - accumulating stations on intermediate channels of irrigation systems and water reservoirs. IOP Conf. Series: Earth and Environmental Science 614 (2020) 012088 doi:10.1088/17551315/614/1/012088

25. Mukhammadiev M.M, Urishev B. U., Abduaziz uulu A, Gadaev S. K, Zhankabylov S.U. Issues of using local energy systems with hydraulic energy storage in the power system of the Republic of Uzbekistan. ICECAE 2020, Tashkent. E3S Web of Conferences 216, 01138 (2020) https://doi.org/10.1051/e3sconf/202021601138 